\title{
Genetic diversity, introgression and relationships among West/Central African cattle breeds
}

\author{
Eveline Mengwi Ibeagha-AwEMu, Oliver Carl JanN, \\ Christina WEIMANN, Georg ERHARDT* \\ Institute of Animal Breeding and Genetics, Justus-Liebig University, Giessen, \\ Ludwigstrasse 21b, 35390 Giessen, Germany
}

(Received 12 January 2004; accepted 17 June 2004)

\begin{abstract}
Genetic diversity, introgression and relationships were studied in 521 individuals from 9 African Bos indicus and 3 Bos taurus cattle breeds in Cameroon and Nigeria using genotype information on 28 markers ( 16 microsatellite, 7 milk protein and 5 blood protein markers). The genotypes of 13 of the 16 microsatellite markers studied on three European (German Angus, German Simmental and German Yellow) and two Indian (Nelore and Ongole) breeds were used to assess the relationships between them and the African breeds. Diversity levels at microsatellite loci were higher in the zebu than in the taurine breeds and were generally similar for protein loci in the breeds in each group. Microsatellite allelic distribution displayed groups of alleles specific to the Indian zebu, African taurine and European taurine. The level of the Indian zebu genetic admixture proportions in the African zebus was higher than the African taurine and European taurine admixture proportions, and ranged from $58.1 \%$ to $74.0 \%$. The African taurine breed, Muturu was free of Indian zebu genes while its counter Namchi was highly introgressed (30.2\%). Phylogenic reconstruction and principal component analysis indicate close relationships among the zebu breeds in Cameroon and Nigeria and a large genetic divergence between the main cattle groups - African taurine, European taurine and Indian zebu, and a central position for the African zebus. The study presents the first comprehensive information on the hybrid composition of the individual cattle breeds of Cameroon and Nigeria and the genetic relationships existing among them and other breeds outside of Africa. Strong evidence supporting separate domestication events for the Bos species is also provided.
\end{abstract}

genetic diversity / introgression / relationship / cattle

\footnotetext{
*Corresponding author: Georg.Erhardt@ agrar.uni-giessen.de
} 


\section{INTRODUCTION}

The need to increase, maintain and conserve genetic diversity in animal and plant species has been recognized [36]. Attention has consequently been turned to this direction with every tool including phenotypic parameters, biochemical and molecular genetic techniques being utilized to assess animal and plant genetic diversity. The job is far from being done especially with regards to African cattle breeds and their unique history of origin. MacHugh et al. [25] in a study on cattle breeds from Africa, Europe and India reported the highest diversity levels in African Bos indicus breeds, which are comparable to diversity levels at a center of origin [22]. The admixed nature of African Bos indicus breeds is thought to be responsible for its increased level of diversity [26]. It is therefore necessary to assess diversity levels in more breeds in the region in order to determine improvement and conservation priorities. This is especially necessary owing to the husbandry systems practiced by local livestock farmers, which may affect diversity levels through the breeding of relatives and high gene flow between breeds.

The issues surrounding the origin and domestication of today's African cattle breeds $[9,10,14,28]$, especially the theory of an African center of domestication for the African taurine $[4,6,15,23,25]$ needs further clarification. The results of several investigations have also indicated that African zebu cattle are an admixture of Bos indicus and Bos taurus [4, 15, 25]. The levels of Asian zebu genes in the African breeds are different and need to be determined for each breed. Some studies have estimated zebu admixture levels at about $50.0 \%$ to $83.0 \%$ in African zebus [15,25] and levels up to $45.0 \%$ in African taurines [15]. In a recent study Achukwi et al. [1] demonstrated that the Namchi (taurine) with a lower level of zebu genes showed a higher level of resistance to trypanosomiasis as compared to another taurine, Kapsiki, which has a higher level of zebu genes. The high levels of zebu genes reported in some African taurine breeds by Hanotte et al. [15] is particularly alarming and the African taurines stand to lose their identity should this trend continue. It is therefore necessary to assess the levels of Asian zebu genes in African cattle breeds, particularly the taurines to enable their continued survival through effective management decisions.

The aim of the study was to assess genetic diversity and introgression levels in Bos indicus and Bos taurus cattle breeds in Cameroon and Nigeria necessary for sustainable management and conservation decisions, and to assess the phylogenetic relationships existing between them and cattle breeds in Europe and Asia with the hope of providing further information on the history of their origins. 


\section{MATERIALS AND METHODS}

\subsection{Studied breeds}

Blood samples were obtained from 9 Bos indicus (zebu) breeds in Cameroon (Red Bororo, $n=52$; White Fulani, $n=44$; Banyo Gudali, $n=77$; Ngaoundere Gudali, $n=55$ ) and Nigeria (Red Bororo, $n=52$; White Fulani, $n=53$; Sokoto Gudali, $n=65$; Adamawa Gudali, $n=11$; Wadara, $n=36$ ) and 3 Bos taurus breeds (Namchi, $n=30$ in Cameroon, and Muturu, $n=20$ and N'Dama, $n=26$, both in Nigeria). The individuals sampled were at distant locations and unrelated. DNA was isolated from white blood cells according to a modified protocol of Montgomery and Sise [31]. In addition, the data of 3 European Bos taurus breeds (German Angus, $n=54$; German Simmental, $n=50$ and German Yellow, $n=50$ ) and 2 Indian Bos indicus breeds (Nelore, $n=54$ and Ongole, $n=60$ ) were included for comparative purposes.

\subsection{Studied markers}

A total of 28 markers including 5 blood protein markers (albumin-ALB, carbonic anhydrase-CA II, vitamin D-binding protein-GC, heamoglobin- $H B B$ and transferrin-TF), 7 milk protein markers $\left(\alpha_{S 1}\right.$-casein 5 ' promoter region-

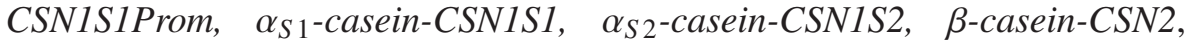
$\kappa$-casein-CSN3, $\alpha$-lactalbumin-LAA and $\beta$-lactoglobulin-LGB) and $16 \mathrm{mi}-$ crosatellite markers (BM1818, BM1824, BM2113, CSSM66, ETH10, ETH152, ETH185, HEL1, HEL5, HEL13, ILSTS6, INRA23, INRA37, SPS115, TGLA122 and TGLA126) were studied. The microsatellites are from a list recommended by the FAO and the International Society for Animal Genetics (http://www.projects.roslin.ac.uk/) for use in cattle biodiversity studies.

\subsection{Genotyping of blood and milk protein markers}

Information on genotyping and allele frequencies of the protein markers (blood and milk) except for the three European taurine breeds and the two Indian zebu breeds are found respectively in Ibeagha-Awemu et al. [18, 19].

\subsection{Genotyping of microsatellite markers}

Microsatellites were PCR amplified using their respective primer pairs as detailed in http://www.projects.roslin.ac.uk/. Amplified PCR products were 
analyzed under denaturing conditions in $0.5 \mathrm{~mm}$ thick polyacrylamide gels $(5.5 \% \mathrm{w} / \mathrm{v}$ acrylamide, $6 \mathrm{M}$ urea) using the half automatic sequencing system A.L.F. express (Amersham Pharmacia, Freiburg, Germany). Allele sizes standardized (with Giessen 2000) to the agreed size of international DNA reference samples (http://www.projects.roslin.ac.uk/) were analyzed with the computer program Allelinks (version 1.00) (Amersham Pharmacia Biotech Europe GmbH, Freiburg, Germany).

Microsatellite data for the European breeds were analyzed within RESGEN Project No CT98-118 while data for the Indian breeds were obtained from CaDBase (Cattle diversity data base, http://www.projects.roslin.ac.uk) and previously reported by Loftus et al. [22].

\subsection{Statistical analysis}

Allele frequencies: Frequencies of alleles at the analyzed loci were estimated using the GENEPOP program (version 3.3) [39].

Heterozygosity and gene diversity: Estimates of observed heterozygosity $\left(H_{\mathrm{ob}}\right)$ and unbiased gene diversity (expected unbiased heterozygosity, $\left.H_{\exp }\right)$ for each breed were obtained with the POPGENE program (version 1.31) [44]. $H_{\text {exp }}$ was estimated using the algorithm of Levene [21], which is the same as Nei's [34] unbiased heterozygosity.

Estimation of genetic admixture proportions: Genetic admixture proportions of the studied breeds were estimated using a coalescent approach $(\mathrm{mY})$ [3], which takes into account allele frequencies and the molecular distances between alleles. Alleles at Indian zebu, African taurine and European taurine diagnostic loci and the program Admix 2.0 [8] were used to estimate $\mathrm{mY}$. The parental populations used were the following: P1 = a pool of genes from two Indian zebu breeds, Nelore and Ongole; P2 = a pool of genes from two African taurine breeds, Muturu and N'Dama; and P3 = a pool of genes from two European taurine breeds, German Angus and German Yellow.

Genetic distances and relationships: Nei's $D_{\mathrm{A}}$ genetic distances [35] were estimated between the African breed pairs on the basis of all markers, and between all breed pairs on the basis of 13 microsatellite markers using the DISPAN program [37]. The Neighbor-joining (N-J) method of Saitou and Nei [40] was applied in phylogeny construction using the NEIGHBOR and DRAWTREE programs of PHYLIP version 3.6b [12].

Principal component (PC) analysis: Principal components were was calculated for all breeds using allele frequencies of 13 microsatellite markers. 
The procedures described by Cavalli-Sforza et al. [5] and the SPSS 10.0 Software (SPSS Inc., Chicago, USA) were used in PC estimates.

\section{RESULTS}

\subsection{Genetic diversity}

In total, 225 alleles were detected at all loci (28). Out of this number, 184 were detected at microsatellite loci, 21 at blood protein loci and 20 at milk protein loci. Estimates of $H_{\mathrm{ob}}$ and $H_{\mathrm{exp}}$ for all loci and breeds are presented in Table I. In general, heterozygosity estimates were the highest for microsatellite markers followed by blood protein and lastly milk protein markers. These estimates were also higher in the African zebus than the taurine breeds. Mean $H_{\mathrm{ob}}$ and $H_{\text {exp }}$ values at microsatellite loci were similar for breeds in the African zebu group $-H_{\mathrm{ob}}$ values ranged from 0.652 to 0.697 and $H_{\exp }$ from 0.703 to 0.744 . In the African taurine group, the lowest and highest $H_{\mathrm{ob}}$ values occurred respectively in Muturu and N'Dama and $H_{\exp }$ in Muturu and Namchi. At blood protein loci Adamawa Gudali had the highest $H_{\mathrm{ob}}$ and $H_{\mathrm{exp}}$ values $(0.473,0.482)$ and Muturu the lowest values $(0.210,0.139)$. Estimates at milk protein loci were different for breeds in the taurine group but generally similar in the zebu group. Overall $H_{\text {exp }}$ estimates within breeds ranged from 0.385 (Muturu) to 0.600 (Cameroonian White Fulani).

\subsection{Microsatellite allelic distribution}

A high disparity in microsatellite allelic distribution between the African zebu and taurine breeds was observed. A total of 184 alleles at different frequencies were identified at the 16 microsatellite loci (data not shown). The most polymorphic locus was ETH185 with 18 alleles and the least polymorphic was ETH152 with 8 alleles. An average of 11.5 alleles occurred per microsatellite locus. $16.9 \%$ (31) of the identified alleles were common to all breeds while $16.3 \%$ (30) were specific to certain breeds. At least one breed specific allele occurred at all loci with the highest number at the BM1824 locus (5) and Nigerian White Fulani breed (7). The Namchi in the taurine group had more alleles in common with the indicine breeds than did the N'Dama and Muturu.

For 10 of the loci (BM1824, BM2113, CSSM66, ETH10, ETH152, HEL1, HEL13, INRA23, ILSTS6 and TGLA122), scored alleles were identified that were present at higher frequencies in breeds in each bio-geographical grouping 
Table I. Mean observed heterozygosities $\left(H_{\mathrm{ob}}\right)$ and unbiased gene diversities $\left(H_{\exp }\right)$ per marker set and breed.

\begin{tabular}{|c|c|c|c|c|c|c|c|c|}
\hline \multirow[b]{2}{*}{ Breed } & \multicolumn{2}{|c|}{ Microsatellites } & \multicolumn{2}{|c|}{ Blood proteins } & \multicolumn{2}{|c|}{ Milk proteins } & \multicolumn{2}{|c|}{ Overall mean } \\
\hline & $H_{\mathrm{ob}}$ & $H_{\exp }$ & $H_{\mathrm{ob}}$ & $H_{\exp }$ & $H_{\mathrm{ob}}$ & $H_{\text {exp }}$ & $H_{\mathrm{ob}}$ & $H_{\text {exp }}$ \\
\hline \multicolumn{9}{|l|}{ Bos indicus } \\
\hline $\begin{array}{l}\text { White Fulani } \\
\text { (Nigeria) }\end{array}$ & 0.657 & 0.730 & 0.460 & 0.456 & 0.337 & 0.377 & 0.542 & 0.593 \\
\hline $\begin{array}{l}\text { White Fulani } \\
\text { (Cameroon) }\end{array}$ & 0.682 & 0.744 & 0.409 & 0.453 & 0.375 & 0.376 & 0.557 & 0.600 \\
\hline $\begin{array}{l}\text { Red Bororo } \\
\text { (Nigeria) }\end{array}$ & 0.697 & 0.717 & 0.392 & 0.417 & 0.376 & 0.370 & 0.562 & 0.577 \\
\hline $\begin{array}{l}\text { Red Bororo } \\
\text { (Cameroon) }\end{array}$ & 0.693 & 0.718 & 0.420 & 0.442 & 0.386 & 0.416 & 0.568 & 0.593 \\
\hline $\begin{array}{l}\text { Sokoto } \\
\text { Gudali }\end{array}$ & 0.697 & 0.731 & 0.419 & 0.429 & 0.343 & 0.386 & 0.559 & 0.591 \\
\hline $\begin{array}{l}\text { Banyo } \\
\text { Gudali }\end{array}$ & 0.654 & 0.724 & 0.445 & 0.452 & 0.342 & 0.377 & 0.539 & 0.589 \\
\hline $\begin{array}{l}\text { Ngaoundere } \\
\text { Gudali }\end{array}$ & 0.692 & 0.703 & 0.418 & 0.449 & 0.286 & 0.316 & 0.541 & 0.561 \\
\hline Wadara & 0.652 & 0.705 & 0.363 & 0.386 & 0.368 & 0.377 & 0.529 & 0.566 \\
\hline $\begin{array}{l}\text { Adamawa } \\
\text { Gudali }\end{array}$ & 0.665 & 0.711 & 0.473 & 0.482 & 0.375 & 0.419 & 0.558 & 0.597 \\
\hline \multicolumn{9}{|l|}{ Bos taurus } \\
\hline Namchi & 0.549 & 0.656 & 0.373 & 0.361 & 0.365 & 0.424 & 0.472 & 0.545 \\
\hline Muturu & 0.506 & 0.512 & 0.210 & 0.139 & 0.218 & 0.269 & 0.381 & 0.385 \\
\hline N'Dama & 0.605 & 0.612 & 0.285 & 0.272 & 0.229 & 0.234 & 0.454 & 0.457 \\
\hline
\end{tabular}

(Africa, Europe and India), and absent or present at relatively lower frequencies in breeds in the other bio-geographical groups (Fig. 1). All the breeds were clearly separated by alleles at three of these loci (ETH10, HEL1 and HEL13). Following the definition of MacHugh et al. [25], these alleles were considered diagnostic or specific for breeds in the bio-geographical groupings. Zebu alleles were identified at seven of the ten loci and their mean frequency distribution was the highest in Indian zebus (63.1\%) followed by African zebus (45.2\%) while being less than $10.0 \%$ in both African and European taurines. For the taurine breeds, German Yellow had the lowest proportion of zebu alleles $(0.1 \%)$ followed by Muturu (0.4\%) while Namchi had the highest $(20.4 \%)$. Due to the higher frequencies of these alleles in the Indian than African zebu, they will henceforth be denoted "Indian zebu specific alleles". 


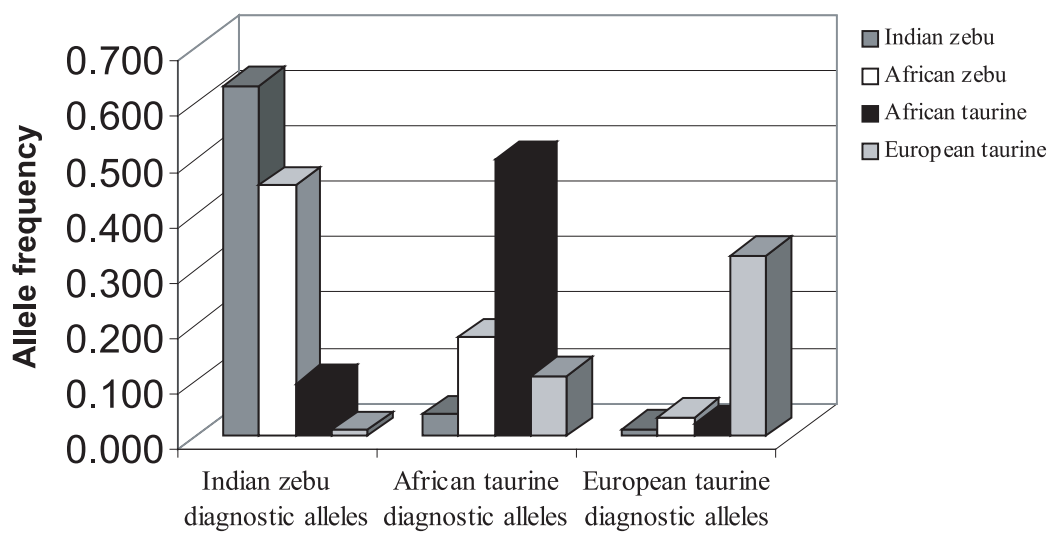

Figure 1. Distribution of group diagnostic/specific alleles across bio-geographical groupings. Indian zebu diagnostic alleles: BM2113-130 and 142 bp; CSSM66-181 bp; ETH10-207, 209 and 211 bp; ETH152-191 bp; HEL1-101, 107 and 117 bp; HEL13-182 and 186 bp; TGLA122-144 bp. African taurine diagnostic alleles: BM1824-181 bp; BM2113-122 bp; ETH10-219 bp; ETH152-195 bp; HEL1-109 bp; HEL13-190; INRA 23-199 bp. European taurine diagnostic alleles: BM1824-189 bp; CSSM66-183 bp; ETH10-215 bp; HEL1-113 bp; HEL13-188 bp; ILSTS6-289 bp; TGLA122-150 bp.

African taurine specific alleles were present at seven loci and their distribution in the African taurines was 56.4\% in Muturu, 53.8\% in N'Dama and $39.0 \%$ in Namchi. Their mean value was higher in the African zebu than the European taurine while the Indian zebu had the lowest value. In fact, only two of the seven African taurine specific alleles were identified in the Indian zebus. Identified European taurine specific alleles were seven at seven loci. Their distribution was the highest as expected in the European taurines $(32.5 \%)$ while being less than $4.0 \%$ in breeds in the other bio-geographical groups.

\subsection{Genetic admixture}

The coefficients of admixture per breed and bio-geographical grouping are presented in Table II. The Indian zebu genetic proportions in the African zebus ranged from 58.1\% (Ngaoundere Gudali) to 74.0\% (Nigerian Red Bororo). The African Namchi in the taurine group received the highest level of Indian zebu genes (30.2\%) while the Muturu and German Angus were very less influenced (negative coefficients). The African taurine influence was above $8.0 \%$ in the African zebus, $11.9 \%$ in the Ongole and $12.9 \%$ in German Angus. Nelore and two European taurines had little or no genes of African taurine origin. 
Table II. Admixture proportions of breeds belonging to the African zebu, Indian zebu, African taurine and European taurine.

\begin{tabular}{llll}
\hline Breed & $\mathrm{mY} 1 \pm \mathrm{SD}$ & $\mathrm{mY} 2 \pm \mathrm{SD}$ & $\mathrm{mY} 3 \pm \mathrm{SD}$ \\
\hline African zebu & & & \\
White Fulani (Nigeria) & $0.705 \pm 0.043$ & $0.075 \pm 0.098$ & $0.220 \pm 0.077$ \\
White Fulani (Cameroon) & $0.664 \pm 0.041$ & $0.230 \pm 0.091$ & $0.106 \pm 0.077$ \\
Red Bororo (Nigeria) & $0.740 \pm 0.042$ & $0.155 \pm 0.089$ & $0.105 \pm 0.073$ \\
Red Bororo (Cameroon) & $0.626 \pm 0.041$ & $0.242 \pm 0.079$ & $0.132 \pm 0.072$ \\
Sokoto Gudali & $0.672 \pm 0.040$ & $0.081 \pm 0.089$ & $0.247 \pm 0.075$ \\
Banyo Gudali & $0.657 \pm 0.040$ & $0.083 \pm 0.090$ & $0.260 \pm 0.068$ \\
Ngaoundere Gudali & $0.581 \pm 0.037$ & $0.292 \pm 0.078$ & $0.127 \pm 0.066$ \\
Wadara & $0.642 \pm 0.049$ & $0.085 \pm 0.113$ & $0.372 \pm 0.093$ \\
Adamawa Gudali & $0.612 \pm 0.076$ & $0.382 \pm 0.106$ & $0.015 \pm 0.098$ \\
Indian zebu & & & \\
Nelore & $0.907 \pm 0.049$ & $-0.051 \pm 0.106$ & $0.143 \pm 0.089$ \\
Ongole & $1.070 \pm 0.045$ & $0.119 \pm 0.108$ & $-0.189 \pm 0.099$ \\
African taurine & & & \\
Namchi & $0.302 \pm 0.064$ & $0.197 \pm 0.133$ & $0.501 \pm 0.089$ \\
Muturu & $-0.129 \pm 0.040$ & $1.084 \pm 0.086$ & $0.045 \pm 0.081$ \\
N'Dama & $0.082 \pm 0.048$ & $0.803 \pm 0.123$ & $0.115 \pm 0.105$ \\
European taurine & & & \\
German Angus & $-0.039 \pm 0.034$ & $0.129 \pm 0.085$ & $0.910 \pm 0.062$ \\
German Simmental & $0.039 \pm 0.053$ & $-0.015 \pm 0.115$ & $0.976 \pm 0.075$ \\
German Yellow & $0.033 \pm 0.032$ & $-0.097 \pm 0.081$ & $1.064 \pm 0.061$ \\
\hline
\end{tabular}

$\mathrm{mY} 1$ = genetic contributions from the Indian zebu; $\mathrm{mY} 2$ = genetic contributions from the African taurine; $\mathrm{mY} 3$ = genetic contributions from the European taurine.

European taurine influence was very evident in the African breeds (1.5 to $37.5 \%$ in the zebus and 4.5 to $50.1 \%$ in the taurines) and the Indian Nelore (14.3\%). Only one breed, Ongole was not influenced by the genes of the European taurine origin.

\subsection{Genetic distances and phylogeny}

Low $D_{\mathrm{A}}$ estimates (Tab. III) were observed between the African zebu breed pairs and higher estimates between the zebu and taurine pairs. The lowest $D_{\mathrm{A}}$ distance was between the Nigerian White Fulani and Sokoto Gudali (0.028) and the highest between the Cameroonian White Fulani and Muturu (0.299). The unrooted tree of phylogeny shows a clear separation between the African zebus and taurine breeds (Fig. 2). Eight of the zebu breeds are to be found in a tight cluster at one end and two taurine breeds, the Muturu and N'Dama at the 
Table III. Matrix of $D_{\text {A }}$ genetic distances between 12 African cattle breeds on the basis of 28 markers (16 microsatellite markers and 12 protein markers) (below diagonal) and between 17 cattle breeds on the basis of 13 microsatellite markers (above diagonal).

\begin{tabular}{|c|c|c|c|c|c|c|c|c|c|c|c|c|c|c|c|c|c|}
\hline \multicolumn{10}{|c|}{ Bos indicus } & \multicolumn{3}{|c|}{ African taurine } & \multicolumn{2}{|c|}{ Indian zebu } & \multicolumn{3}{|c|}{ European taurine } \\
\hline & WFn & WFc & $\mathrm{RBn}$ & $\mathrm{RBc}$ & SG & BG & NG & WD & AG & NA & MT & ND & NEL & ONG & GEA & GES & GEY \\
\hline WFn & - & 0.079 & 0.050 & 0.045 & 0.042 & 0.040 & 0.065 & 0.068 & 0.116 & 0.126 & 0.347 & 0.236 & 0.230 & 0.206 & 0.375 & 0.347 & 0.419 \\
\hline WFc & 0.052 & - & 0.098 & 0.085 & 0.070 & 0.095 & 0.110 & 0.116 & 0.154 & 0.184 & 0.394 & 0.299 & 0.273 & 0.251 & 0.399 & 0.372 & 0.429 \\
\hline $\mathrm{RBn}$ & 0.032 & 0.058 & - & 0.056 & 0.058 & 0.063 & 0.074 & 0.092 & 0.142 & 0.134 & 0.362 & 0.245 & 0.244 & 0.219 & 0.412 & 0.375 & 0.445 \\
\hline $\mathrm{RBc}$ & 0.034 & 0.052 & 0.034 & - & 0.052 & 0.043 & 0.070 & 0.082 & 0.115 & 0.123 & 0.357 & 0.261 & 0.254 & 0.210 & 0.375 & 0.339 & 0.412 \\
\hline SG & 0.027 & 0.046 & 0.033 & 0.033 & - & 0.052 & 0.061 & 0.070 & 0.119 & 0.120 & 0.332 & 0.237 & 0.241 & 0.226 & 0.374 & 0.345 & 0.414 \\
\hline BG & 0.037 & 0.056 & 0.039 & 0.031 & 0.033 & - & 0.064 & 0.080 & 0.120 & 0.135 & 0.350 & 0.252 & 0.238 & 0.289 & 0.355 & 0.314 & 0.395 \\
\hline $\mathrm{NG}$ & 0.055 & 0.074 & 0.051 & 0.052 & 0.046 & 0.046 & - & 0.097 & 0.120 & 0.113 & 0.335 & 0.237 & 0.273 & 0.248 & 0.384 & 0.317 & 0.411 \\
\hline WD & 0.051 & 0.078 & 0.058 & 0.054 & 0.047 & 0.058 & 0.065 & - & 0.157 & 0.132 & 0.345 & 0.246 & 0.267 & 0.227 & 0.397 & 0.373 & 0.427 \\
\hline$A G$ & 0.090 & 0.106 & 0.095 & 0.077 & 0.084 & 0.089 & 0.094 & 0.096 & - & 0.167 & 0.293 & 0.234 & 0.352 & 0.316 & 0.455 & 0.391 & 0.461 \\
\hline NA & 0.100 & 0.124 & 0.101 & 0.090 & 0.091 & 0.104 & 0.105 & 0.110 & 0.123 & - & 0.222 & 0.137 & 0.390 & 0.353 & 0.359 & 0.309 & 0.378 \\
\hline MT & 0.284 & 0.299 & 0.286 & 0.271 & 0.266 & 0.277 & 0.290 & 0.293 & 0.231 & 0.171 & - & 0.192 & 0.620 & 0.627 & 0.361 & 0.329 & 0.431 \\
\hline ND & 0.207 & 0.227 & 0.204 & 0.200 & 0.193 & 0.205 & 0.213 & 0.216 & 0.183 & 0.121 & 0.124 & - & 0.480 & 0.466 & 0.351 & 0.323 & 0.392 \\
\hline NEL & & & & & & & & & & & & & - & 0.087 & 0.544 & 0.491 & 0.561 \\
\hline ONG & & & & & & & & & & & & & & - & 0.552 & 0.528 & 0.587 \\
\hline GEA & & & & & & & & & & & & & & & - & 0.167 & 0.190 \\
\hline GES & & & & & & & & & & & & & & & & - & 0.125 \\
\hline GEY & & & & & & & & & & & & & & & & & - \\
\hline
\end{tabular}

WFn: Nigerian White Fulani, WFc: Cameroonian White Fulani, RBn: Nigerian Red Bororo, RBc: Cameroonian Red Bororo, SG: Sokoto Gudali, BG: Banyo Gudali, NG: Ngaoundere Gudali, WD: Wadara, AG: Adamawa Gudali, NA: Namchi, MT: Muturu, ND: N'Dama, NEL: Nelore, ONG: Ongole, GEA: German Angus, GES: German Simmental, GEY: German Yellow. 


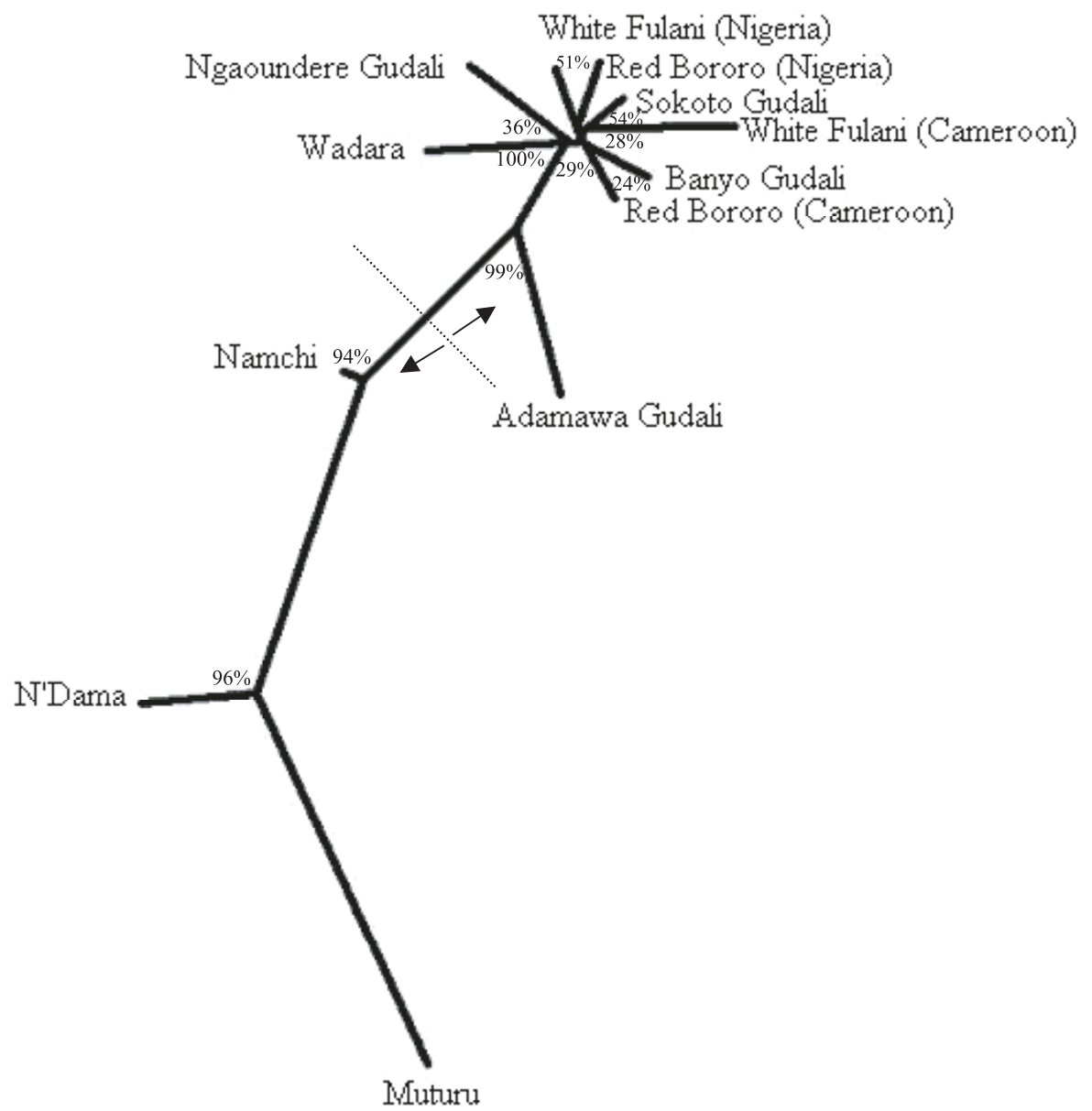

Figure 2. Unrooted neighbor-joining tree constructed from $D_{\mathrm{A}}$ distances showing the relationships among 12 African cattle breeds ( 9 zebus and 3 taurines). Genetic distances are based on 28 markers ( 16 microsatellite, 5 blood protein and 7 milk protein markers).

other end. The Adamawa Gudali and Namchi occupied the central region but with each closer to its own breed group.

As expected, large $D_{\mathrm{A}}$ estimates (Tab. III) on the basis of 13 markers considering all 17 breeds were observed between breed pairs of one breed group and another while lower distances occurred between members within the same group. 


\subsection{Principal components of allele frequency distributions}

The result of PC on the allele frequencies of 13 microsatellite markers on all breeds is presented in Figure 3, and further explains the relationships existing among these breeds. Three groups were each evident on the basis of the 1st $(40.1 \%)$ and 2 nd (24.3\%) PC values and clearly portray the magnitude of divergence between them. The three groups under the 1st PC were the Indian zebus, African zebus and African/European taurines and under the 2nd PC, European taurines/Indian zebus, African zebus and African taurines. The separation between the African taurines and European taurines was clear under the 2nd PC and between European taurines and Indian zebus under the 1st PC. The African zebus on the basis of both $\mathrm{PC}$ values occupied a position midway between the two extremes - African taurines and Indian zebus.

\section{DISCUSSION}

A high number of unique microsatellite alleles in the African zebu breeds are suggestive of a large effective population size and thus the retention of these alleles. The general absence of unique alleles in the taurine breeds is supported by their low population size. Encroaching zebu breeds into the humid zone with the help of veterinary prophylaxes have forced the few remaining taurine populations into limited locations in the zone. All the African taurine breeds in this study are at risk of endangerment [11,29].

Microsatellite allelic distribution in the breeds is a further proof of the heavy influence of Indian zebu cattle and taurine (African and European) breeds on the zebu breeds in Africa. This is evident by the distribution of group specific microsatellite alleles, especially Indian zebu specific and African taurine specific alleles in these breeds. Some of the Indian zebu diagnostic loci/alleles observed in this study have been previously described [22, 25, 30]. Alleles at the diagnostic loci ETH152 and HEL1 described by MacHugh et al. [25] are the same observed here except ETH152 193 and HEL1 ${ }^{111}$. Zebu specific alleles have also been reported at blood and milk protein loci $[18,19]$. The observation of African taurine diagnostic loci/alleles in this study is supported by MacHugh [24], who, however, did not report European taurine diagnostic alleles. European taurine diagnostic allele 113 bp of HEL1, a locus also considered by MacHugh [24], was completely absent in all the African taurines and Indian zebus in this study, and only present in one African zebu breed at a low frequency of 0.021 . African taurine specific allele INRA $37^{114}$ described by Moazami-Goudarzi et al. [30] was absent in the Namchi and N'Dama breeds 


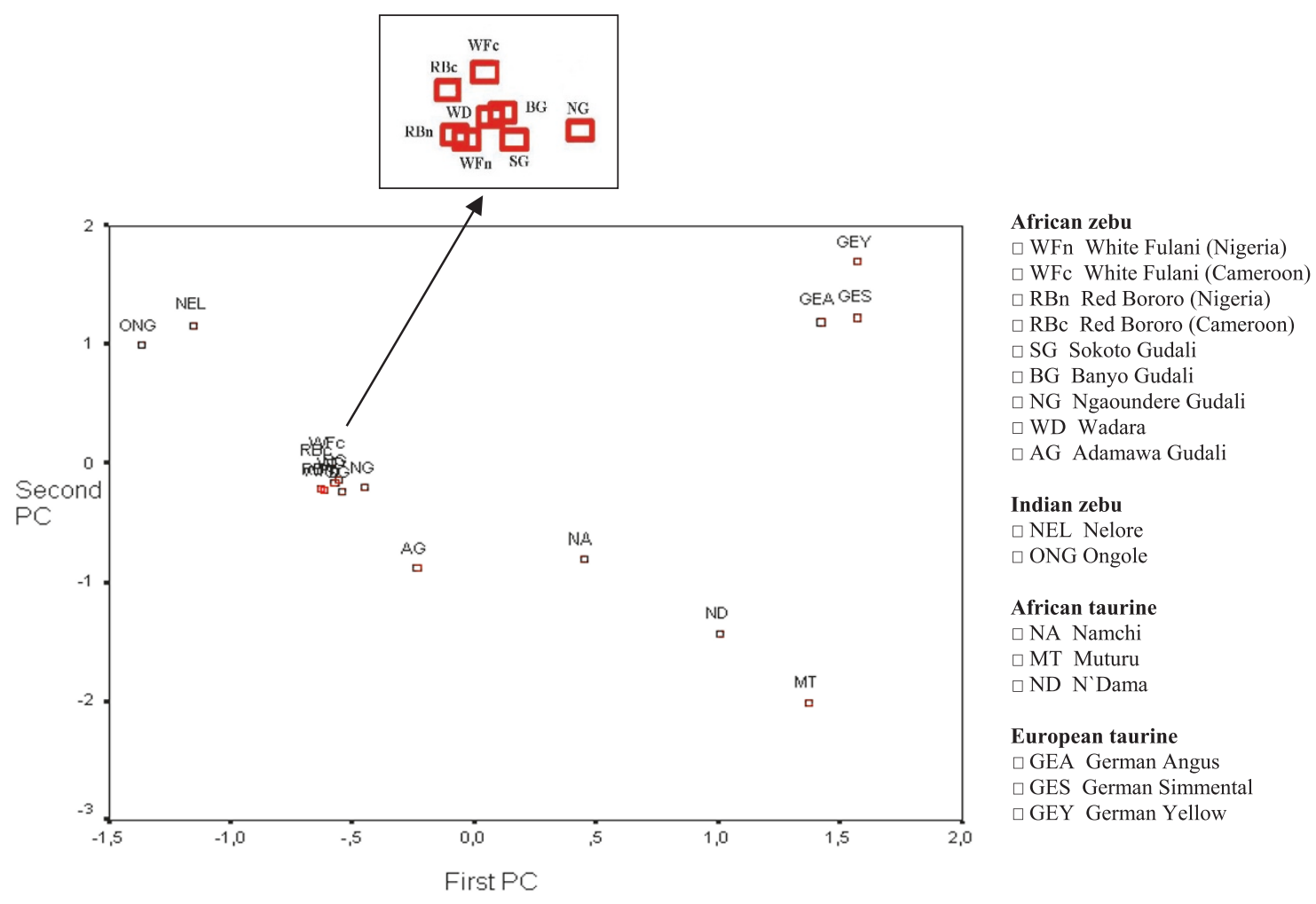

Figure 3. Scatter plot of principal component analysis of allele frequencies at 13 microsatellite markers of 9 African zebu breeds, 3 African taurines, 2 Indian zebus and 3 European taurines. The African zebu cluster is further magnified and shown in a box at the top of the scatter plot. 1st PC $=40.1 \%$ and 2 nd $\mathrm{PC}=24.3 \%$. 
and occurred at a low frequency $(3.1 \%)$ in the Muturu breed. This allele was consequently not considered African taurine specific in this study. The distribution of European taurine specific alleles was even more surprising, from a mean frequency of 0.325 in the European taurines to 0.013 in the Indian zebus. Even in the African taurines, a mean frequency of 0.022 for these alleles was far from expectation and was therefore indicative of a large evolutionary divergence between African and European taurines.

The general distribution of group specific alleles concurred with distance and history of breed development. The trend for Indian zebu diagnostic alleles (Indian zebu $>$ African zebu $>$ African taurine $>$ European taurine) is supported by the history of introduction of zebu genes into Africa and Europe [10,15] and by investigations with other markers, which show a higher number of allele sharing between Indian and African zebu breeds [27, 33, 38]. In a recent study, Loftus et al. [22] also recorded the presence of Indian zebu diagnostic alleles in some European cattle breeds, Hungarian Grey (2.2\%) and Turkish Grey (10.4\%). The distribution of group specific alleles could be interpreted as the retention of a higher number of alleles at these locations (Africa, Europe, India), here regarded centers of origin, and a large evolutionary divergence between them.

The estimator mY [3] was adopted in assessing the admixture proportions of the breeds in this study because it is particularly suited for the assessment of admixed populations with distant parental lines and has been shown to perform well in most situations [7]. The admixture coefficients and the proportion of group specific alleles have indicated the extent of their influence on the zebu breeds in Cameroon and Nigeria, with a heavier influence coming from the Indian zebus. The fact that no microsatellite alleles were specific to the African zebus is a confirmation of their composite nature. The Indian zebus less influenced some of the African and European taurines. The proportion of zebu alleles at microsatellite loci in the Namchi and N'Dama breeds and the observations of a heavy zebu influence at milk and blood protein loci $[18,19]$ could be recent and probably not a primary influence from Indian breeds, but secondary through the established admixed African zebus. Similar high levels of introgression of Indian zebu genes into African zebu breeds have been reported by MacHugh et al. [25] (59.8-83.2\%) and Hanotte et al. [15] (54.8-83.2\%). The admixed compositions of African zebu breeds are also evident through the analysis of other autosomal markers, sex chromosomes and mitochondria DNA $[2,4,13,16,25]$. The hybrids also predominate over the taurines in today's Cameroon and Nigeria and may be explained by the migratory and war history of the people of Africa. The main Arab invasion of 700 AD, 
the outbreak of diseases [9], many Muslim holy wars in the West African region during the 19th century [32] and encroaching arid conditions could have contributed to the distribution of zebu genes in African cattle breeds. Encroaching zebu breeds continue to be a threat to the few remaining taurine populations through secondary introgressions, with the examples being the Namchi and N'Dama breeds in this study, N'Dama populations in MacHugh et al. [25] and several taurine breeds in Hanotte et al. [15]. The estimated zebu influence at microsatellite loci $(30.2 \%)$ on the Namchi breed is lower than at blood protein loci $(61.5 \%)$ [18], and on the basis of trypanotolerance, indicates a greater danger of dilution from candidate genes than from neutral markers. A study by Achukwi et al. [1] indicated that the taurine breed Kapsiki with a higher level of zebu genes than Namchi was more prone to trypanosomal infection.

It is clear from this study that Bos taurus (European and African) and Bos indicus cattle possess very distinct allelic distributions and that zebu breeds in Cameroon and Nigeria have a mixture of both African/European Bos taurus and Indian zebu alleles, thus substantiating their high diversity status. Genetic diversity of African zebu breeds is higher than the values reported for most European taurine breeds [17,22,25] and Indian zebu breeds [22,25], and compares to reports on other African Bos indicus breeds [25,30], breeds in Turkey, and the Near East [22] and Korean and Chinese cattle [20]. Loftus et al. [22] interpreted high gene diversity in the Near Eastern breeds as having resulted from a retention of a high number of alleles by populations in a center of origin and also an influence from Indian zebu breeds. A higher diversity level in the Namchi breed as compared to the Muturu and N'Dama could be seen as an influence from the zebu breeds. This was justified by the observed higher level of zebu genes in Namchi than in the Muturu and N'Dama.

The observed $D_{\mathrm{A}}$ genetic distances measured among the cattle breeds in Cameroon and Nigeria, and among cattle breeds in the different continents are supported by the long divergence period reported between Bos taurus and Bos indicus cattle breeds [23, 25]. The very close relationship for the zebu breeds in Cameroon and Nigeria was surprising. The breeds are quite distinct phenotypically and one would have expected this to be reflected in the dendrogram and PC of relationships. Even though it is considered that the Gudalis are among the true shorthorn zebus of West Africa [42], an examination of the mY1 admixed coefficients gave this credit rather to the Nigerian Red Bororo. Adamawa Gudali was the zebu that diverged the most from the others. Its low sample size and the high genetic contribution $(\mathrm{mY} 2=38.2 \%)$ from the African taurine could be responsible for this behavior. Close relationships for the zebus may be the consequence of management practices that promote high gene 
flow between them while slight differences could be attributed to genetic drift, which is in line with the migratory histories of the Fulani people. Clustering in the African tree also agreed with the origins of the breeds. The status of the two main species (Bos indicus and Bos taurus) was clearly defined, indicating therefore a large divergence between them. Namchi, however, clustered closer to the zebus owing to the relatively high level $(\mathrm{mY} 1=30.2 \%)$ of Bos indicus genes in them. This observation on the Namchi is similar to an earlier observation on another African taurine breed, the Kuri [41]. The Namchi is traditionally found at the Northwestern foothills of the Poli Mountains in the North Province of Cameroon about $400 \mathrm{~km}$ south of Lake Chad, the habitat of the Kuri cattle. The two breeds by virtue of their location could have been more exposed to crossbreeding with the zebu breeds, thus substantiating their high levels of zebu genes.

The groupings (African zebu, African taurine, Indian zebu and European taurine) observed after multivariate variations between all 17 breeds have thrown more light on their origin and domestication histories. The transitional position of the African zebu between the other breed groups has been clarified by their admixed coefficients while positioning of the other groups is evidence of a high genetic divergence between them. The African taurine influence on the African zebus was higher than the European taurine influence. Based on these findings, a high influence of European Bos taurus genes of up to $74.0 \%$ on other cattle breeds in the continent as indicated by Hanotte et al. [15] is probably a joint influence from African and European taurines. Recent efforts by the Governments of Cameroon and Nigeria in the colonial and immediate postcolonial era to further introduce European taurine genes in the region through upgrading programs did not succeed. This is understandable because grade animals could not survive the harsh environments of the tropics.

In light of the large divergence between the Bos species in this study, suggestions of separate domestication events in the different continents, especially an African center of domestication for African taurine [4, 15, 23, 25, 43] are supported.

It is concluded from this study that cattle breeds in Cameroon and Nigeria are a unique part of the global animal genetic resource. Their hybridized status and high diversity levels present ingredients necessary for breed improvement, development and conservation. High levels of zebu gene introgression in the Namchi African taurine breed stand to threaten its special characteristic of trypanotolerance. Sustainable management decisions must be aimed at limiting zebu genetic exchanges with the taurines, while maintaining diversity for future exploitation. The nine zebu breeds in Cameroon and Nigeria are closely 
related and are stabilized hybrids of Indian Bos indicus and African/European Bos taurus. They are also highly diverged from their counterpart taurines. High genetic divergence between the Bos species in Africa, Europe and India is supportive evidence that they could have been domesticated independently.

\section{ACKNOWLEDGEMENTS}

The German Academic Exchange Service (DAAD) provided financial support towards the realization of the project. We thank the RESGEN consortium (RESGEN-CT98-118) for providing the microsatellite data for the three European breeds.

\section{REFERENCES}

[1] Achukwi M.D., Tanya V.N., Hill E.W., Bradley D.G., Meghen C., Sauveroche B., Banser J.T., Ndoki J.N., Susceptibility of the Namchi and Kapsiki cattle of Cameroon to trypanosome infection, Trop. Anim. Health Prod. 4 (1997) 219-226.

[2] Baker C.M.A., Manwell C., Chemical classification of cattle. 1. Breed groups, Anim. Blood Groups Biochem. Genet. 11 (1980) 127-150.

[3] Bertorelle G., Excoffier L., Inferring admixture proportions from molecular data, Mol. Biol. Evol. 15 (1998) 1298-1311.

[4] Bradley D.G., MacHugh D.E., Cunningham P., Loftus R.T., Mitochondria diversity and the origins of African and European cattle, Proc. Natl. Acad. Sci. USA 93 (1996) 5131-5135.

[5] Cavalli-Sforza L.L., Menozzi P., Piazza A., The History and Geography of Human Genes, N.J. Princeton University Press, Princeton, 1994.

[6] Ceriotti G., Caroli A., Rizzi R., Crimella C., Genetic relationships among taurine (Bos taurus) and zebu (Bos indicus) populations as revealed by blood groups and blood proteins, J. Anim. Breed. Genet. 120 (2003) 57-67.

[7] Choisy M., Franck P., Cornuet M., Estimating admixture proportions with microsatellites: comparison of methods based on simulated data, Mol. Ecol. 13 (2004) 955-968.

[8] Dupanloup I., Bertorelle G., Computing admixture coefficients from molecular data, http://web.unife.it/progetti/genetica/Isabelle/admix2_0.html (2000).

[9] Epstein E., The Origin of the Domestic Animals of Africa, Vol. I, Africana Publishing Corporation, New York, 1971.

[10] Epstein E., Mason I.L., Cattle, in: Mason I.L. (Ed.), Evolution of Domestic Animals, Longman, London, UK, 1984, pp. 6-27.

[11] FAO, World Watch List for Domestic Animal Diversity, 3rd edn., Food and Agricultural Organization, Rome, 2000.

[12] Felsenstein J., PHYLIP: Phylogeny Inference Package, version 3.6b, http://evolution.gs. Washington.edu/phylip.html (2004). 
[13] Frisch J.E., Drinkwater D., Harrison B., Johnson S., Classification of the southern African sanga and east African shorthorned zebu, Anim. Genet. 28 (1997) 77-83.

[14] Grigson C., The craniology and relationships of four species of Bos. 5. Bos indicus L., J. Arch. Sci. 7 (1980) 3-32.

[15] Hanotte O., Bradley D.G., Ochieng J.W., Verjee Y., Hill E.W., Rege J.E.O., African pastoralism: genetic imprints of origins and migrations, Science 296 (2002) 336-339.

[16] Hanotte O., Tawah C.L., Bradley D.G., Okomo M., Verjee Y., Ochieng J., Rege J.E.O., Geographic distribution and frequency of a taurine Bos taurus and an indicine Bos indicus Y specific allele amongst sub-saharan African cattle breeds, Mol. Ecol. 9 (2000) 387-396.

[17] Hanslik S., Harr B., Brem G., Schlötterer C., Microsatellite analysis reveals substantial genetic differentiation between contemporary New World and Old World Holstein Friesian populations, Anim. Genet. 31 (2000) 31-38.

[18] Ibeagha-Awemu E.M., Jäger S., Erhardt G., Polymorphisms in blood proteins of Bos indicus and Bos taurus cattle breeds of Cameroon and Nigeria, and description of new albumin variants, Biochem. Genet. 42 (2004) 181-197.

[19] Ibeagha-Awemu E.M., Prinzenberg E.-M., Erhardt G., High variability of milk protein genes in Bos indicus cattle breeds of Cameroon and Nigeria, J. Dairy Res. (2004) (in press).

[20] Kim K.S., Yeo J.S., Choi C.B., Genetic diversity of north-east Asian cattle based on microsatellite data, Anim. Genet. 33 (2002) 201-204.

[21] Levene H., On a matching problem in genetics, Ann. Math. Stat. 20 (1949) 91-94.

[22] Loftus R.T., Ertugrul O., Harba A.H., El-Barody M.A.A., MacHugh D.E., A microsatellite survey of cattle from a center of origin: the near east, Mol. Ecol. 8 (1999) 2015-2022.

[23] Loftus R.T., MacHugh D.E., Bradley D.G., Sharp P.M., Cunningham E.P., Evidence for two independent domestication of cattle, Proc. Natl. Acad. Sci. USA 91 (1994) 2757-2761.

[24] MacHugh D.E., Molecular Biogeography and Genetic Structure of Domesticated Cattle, Ph.D. Thesis, Department of Genetics, Trinity College, University of Dublin, 1996.

[25] MacHugh D.E., Shriver M.D., Loftus R.T., Cunningham P., Bradley D.G., Microsatellite DNA variation and the evolution, domestication and phylogeography of taurine and zebu cattle (Bos taurus and Bos indicus), Genetics 146 (1997) 1071-1086.

[26] Mahé M.F., Miranda G., Queval R., Bado A., Souvenir Zafindrajaona P., Grosclaude F., Genetic polymorphism of milk proteins in African Bos taurus and Bos indicus populations. Characterization of variants $\alpha_{\mathrm{S} 1}-\mathrm{Cn} \mathrm{H}$ and $\kappa-\mathrm{Cn}$, Genet. Sel. Evol. 31 (1999) 239-253.

[27] Malik S., Kumar S., Rani R., $\kappa$-casein and $\beta$-casein alleles in crossbred and zebu cattle from India using polymerase chain reaction and sequence-specific oligonucleotide probes, J. Dairy Res. 67 (2000) 295-300. 
[28] Marshall F., Rethinking the role of Bos indicus in sub-saharan Africa, Curr. Anthrop. 30 (1989) 235-240.

[29] Mason I.L., A World Dictionary of Livestock Breeds, Types and Varieties, 4th edn., CAB International, Wallingford, UK, 1996.

[30] Moazami-Goudarzi K., Belemsaga D.M.A., Ceriotti G., Laloë D., Fagbohoun F., Kouagou N'T., Sidibé I., Codjia V., Crimella M.C., Grosclaude F., Touré S.M., Caractérisation de la race bovine Somba à l'aide de marqueurs moléculaires, Rev. Élev. Méd. Vét. Pays Trop. 54 (2001) 129-138.

[31] Montgomery G.W., Sise J.A., Extraction of DNA from sheep white blood cells, New Zealand J. Agric. Res. 33 (1990) 437-441.

[32] Murray L., The Jihad movements of the nineteenth century, in: Ajayi J.F.A., Crowder M. (Eds.), History of West Africa, Vol. 2, Longman Group Ltd, London, 1974, pp. 1-29.

[33] Naik S.N., Sukumaran P.K., Sanghvi L.D., Haemoglobin polymorphism in Indian Zebu cattle, Heredity 24 (1969) 239-247.

[34] Nei M., Molecular Evolutionary Genetics, Columbia University Press, New York, 1987.

[35] Nei M., Tajima F., Tateno Y., Accuracy of estimated phylogenetic trees from molecular data, J. Mol. Evol. 19 (1983) 153-170.

[36] Oldenbrock J.K., Introduction, in: Oldenbrock J.K. (Ed.), Genebanks and the Conservation of Farm Animal Genetic Resources, ID-Lelystad, The Netherlands, 2002, pp. 1-31.

[37] Ota T., DISPAN. Genetic Distance and Phylogenetic Analysis, Institute of Molecular Evolutionary Genetics, Pennsylvania State University, University Park, PA, USA, 1993.

[38] Penedo M.C.T., Mortari N., Magalhaes L.E., Carbonic anhydrase polymorphism in Indian Zebu cattle, Anim. Blood Groups Biochem. Genet. 13 (1982) 141-143.

[39] Raymond M., Rousset F., GENEPOP. Population genetics software and ecumenicism, J. Hered. 86 (2001) 248-249, http:/wbiomed.curtin.edu.au/genepop/.

[40] Saitou N., Nei M., The neighbour-joining method: a new method for reconstructing phylogenetic trees, Mol. Biol. Evol. 4 (1987) 406-425.

[41] Souvenir Zafindrajaona P., Zeuh V., Moazami-Goudarzi K., Idriss A., Grosclaude F., Étude de statut phylogénétique du bovin Kouri du lac Tchad à l'aide de marqueurs moléculaires, Rev. Élev. Méd. Vét. Pays Trop. 52 (1999) $152-162$.

[42] Tawah C.L., Rege J.E.O., Gudali cattle of West and Central Africa, Anim. Genet. Res. Inf. 17 (1996) 159-178.

[43] Troy C.S., MacHugh D.E., Bailey J.F., Magee D.A., Loftus R.T., Cunningham P., Chamberlain A.T., Sykes B.C., Bradley D.G., Genetic evidence for Near-Eastern origins of European cattle, Nature 410 (2001) 1088-1091.

[44] Yeh F.C., Yang R.-C., Boyle T., POPGENE Version 1.31. Microsoft Windows-based freeware for population genetics analysis, ftp://ftp.microsoft.com/Softlib/MSLFILES/HPGL.EXE, or http://www.ualberta.ca/ fyeh/fyeh/ (1999). 